\title{
Relationship marketing and consumer buying behavior in food and beverage firms in port harcourt metropolis
}

\author{
Godswill Chinedu Chukwu', PhD. \\ ${ }^{I}$ Department of Marketing, \\ Ignatius Ajuru University of Education \\ Port Harcourt, Rivers state Nigeria \\ gdwills202@yahoo.com \\ Miyene Charles Tom ${ }^{2}$ \\ ${ }^{1}$ Department of Marketing, \\ Ignatius Ajuru University of Education \\ Port Harcourt, Rivers state Nigeria \\ Miyenetom31@gmail.com
}

\begin{abstract}
This study investigated the impact of relationship marketing on consumer buying behavior in the food and beverage firms in Port Harcourt metropolis. The study also seeks to find out whether considerable pricing system, quality product and service offering and effective and efficient customer service unit affect consumer buying behavior. This study adopted descriptive research design. The populations are all customers of all food and beverage drinks firms in Port Harcourt. A sample size of 375 persons was randomly selected while 358 questionnaires were successfully retrieved and used for the analysis. Sample size was determined using Morgan Krejcie table (1970). Data was collected by use of questionnaire. Three research questions were posed and three hypotheses were tested. Data were analyzed using descriptive statistics while inferential statistics e.g. Pearson product moment correlation coefficient was used to test the stated hypothesis at 0.05 level of significance. Findings revealed that food and beverage firms in Port Harcourt lack considerable pricing system which affect consumer buying behavior negatively; that quality product and service offering impact customers' referral and that effective and efficient customer service unit enhance customer loyalty in food and beverage firms in Port Harcourt. The study concluded that relationship marketing affect consumer buying behavior in food and beverage firms in Port Harcourt. The study therefore recommends that the food and beverage firms in Port Harcourt should be more responsible in providing considerable pricing system in order to attract customers to repeat purchase, that they should implement policies to improve the quality of products and services rendered to customers and also, the food and beverage firms in Port Harcourt should prioritize the stabilization of an effective and efficient customer service unit in order to maintain a maximum degree of customer loyalty.
\end{abstract}

Keywords: relationship marketing, considerable pricing system, quality product and service offering, effective and efficient customer service unit and consumer buying behavior.

\section{Introduction}

\section{Background of Study}

In marketing, there is an enduring custom that has consistently improved relationships, despite the fact that the term "relationship marketing" has just accomplished notoriety in the nineties. Gronroos (2004) stated that the wonder itself is as old as the historical backdrop of exchange and business, and Moller and Halinen (2000) concede that marketing relationships as marvels are presumably as old as any exchange relationships. Indeed, purchaser merchant relationship is a good old method of working together. Relationships have solid verifiable precursors from the pre-modern time (Sheth and Parvatiyar 1995). Venders knew every one of their purchasers independently and recommended proper, redid item contributions. As this order picked up force, and created through the principal three quarters of the twentieth century, the essential spotlight was on exchanges and trades. Be that as it may, the 
improvement of marketing as a field of study and practice is going through a reconceptualization in its direction from exchanges to relationships (Kotler 1990; Webster 1992). The accentuation on relationships instead of exchange based trades is probably going to rethink the area of marketing (Sheth, Nursery worker and Garett 1988). For sure, the rise of a relationship marketing way of thinking is imminent given the developing enthusiasm of marketing researchers in the social worldview.

Relationship marketing endeavors to include and coordinate clients, providers and other infrastructural accomplices into an association's formative and marketing activities (McKenna 1991; Shani and Chalasani 1991). Such inclusion brings about close intuitive relationships with providers, clients or other value chain benefits of the firm. Intuitive relationships between marketing entertainers are natural when contrasted with the arm's length relationships suggested under the conditional direction (Parvatiyar, Shethand Whittington 1992). An integrative relationship accept cover in the plans and processes of the interfacing parties and proposes close monetary, enthusiastic and structural bonds among them. It reflects relationship instead of autonomy of decision among the gatherings; and it underlines collaboration instead of rivalry and resulting strife among the marketing entertainers.

The reason for relationship marketing is, consequently, to improve marketing productivity by accomplishing productivity and viability (Sheth and Sisodia 1995). Several relationship marketing practices can help accomplish productivity, for example, client maintenance, proficient consumer reaction (ECR), and the sharing of assets between marketing accomplices. Every one of these exercises can possibly diminish working expenses of the advertiser. Likewise, more noteworthy marketing viability can be accomplished on the grounds that it attemptsto include clients in the beginning phases of marketing program improvement, encouraging the future marketing endeavors of the organization. Additionally, through individualized marketing and reception of mass customization measures, relationship advertisers can all the more likely location the requirements of each chose client, making marketing more powerful. In the present time of the consistently changing business condition, numerous organizations endeavor hard for their food and their stake in the market. With the developing progression of innovation, the developing globalization, expanding financial inclusion of organizations in outside nations and the rising political obstruction in corporate world. It is getting extremely trying for associations to oversee and build up their business. They think of a few systems to make ideal usage of their assets.

They likewise bend over backward to limit their expenses and create greatest income. Notwithstanding, associations can't achieve their destinations in the event that they have lean 'marketing procedures'. Consumer conduct includes the investigation of people and the technique they utilize to pick, use, and set out items and administrations to satisfy their needs and the impact that these strategy have on the consumer and the general public all in all. "Consumer conduct is the investigation of the cycle included when people or gatherings select, buy, utilize or discard items, administrations, thoughts or encounters to fulfill needs and wants (Solomon et al, 2006). "

\section{Statement of the Problem}

The existence, development, and growth rate of the consumer aspect in Nigeria showed expanded improvement to the Nigerian economy. Regardless of this positive neglect, utilization has to some degree obliged in the ongoing past. With ongoing emergency in Nigeria, Cataclysmic events, for example, floods, environmental change, mutual issues, and fear based oppressor assault which taken negatively affecting food delivering unpaid debts has come about into food deficiencies, food-borne diseases which has added to diminished specialist profitability with respect to cultivating networks and has come about into significant expense of food things, subsequently influencing the quality and amount of the results of food and beverage firms in Nigeria, particularly in Port Harcourt (Uko 2018). The current investigation tried to look at the effect of the components of relationship marketing on the consumer buying conduct of food and beverage firms in Port Harcourt city. 
Conceptual Framework

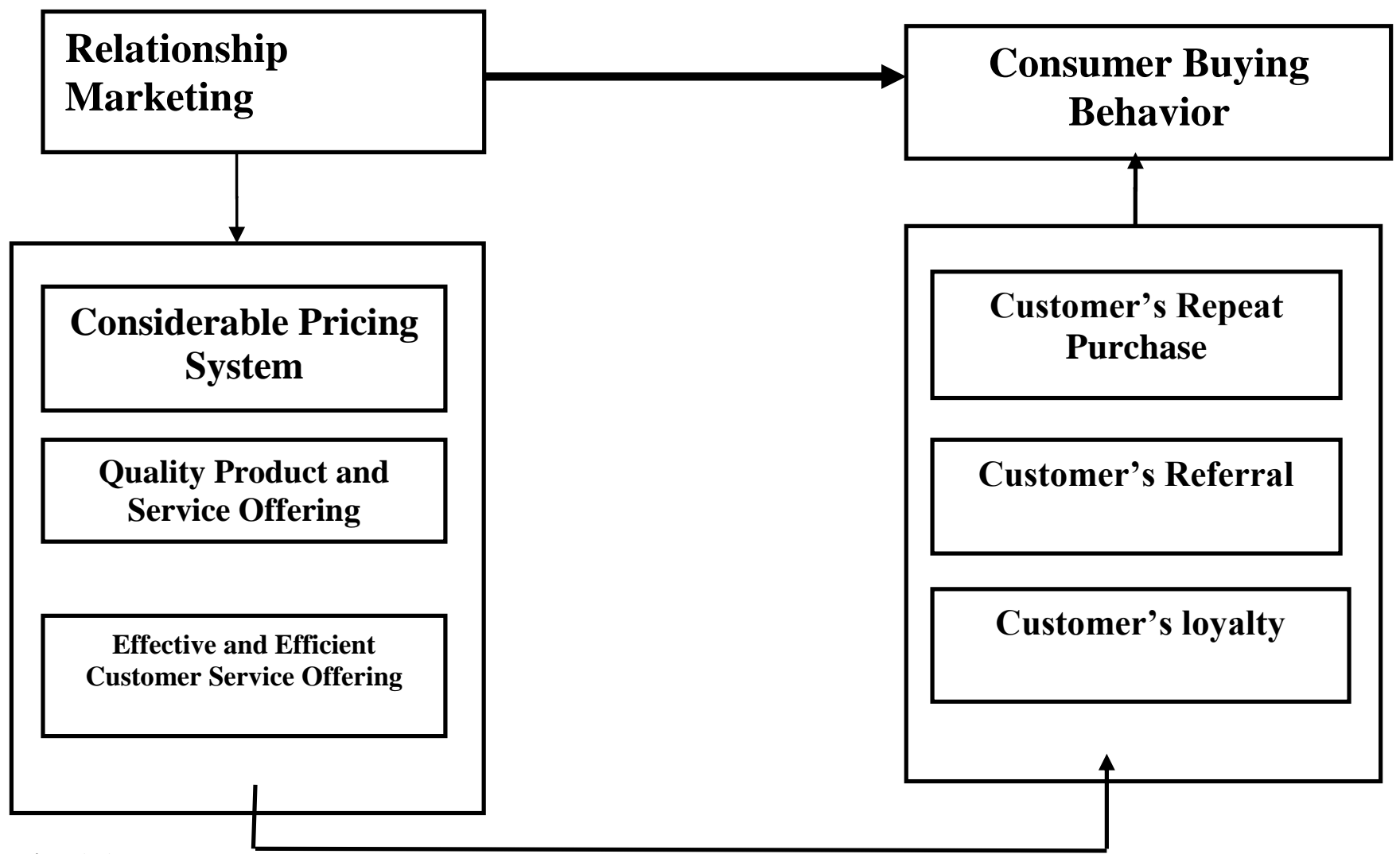

Fig. 1.1

Source: Researchers' concept (2019)

\section{Objectives of the study}

The purpose of this study is to determine the impact of relationship marketing on consumer buying behavior in food and beverage firms in Port Harcourt. The specific objectives are to:

1. Examine the effect of considerable pricing system on customers' repeat purchase in food and beverage firms in Port Harcourt metropolis.

2. Find out the extent of quality product and service offering on customers' referral in food and beverage firms in Port Harcourt metropolis.

3. Determine the impact of effective and efficient customer service offering on customers' loyalty in food and beverage firms in Port Harcourt metropolis.

\section{Research Questions}

The following research questions guided the study:

1. Do considerable pricing system affect customers' repeat purchase in the food and beverage firms in Port Harcourt metropolis?

2. Do quality product and service offering enhance customers' referral food and beverage firms in Port Harcourt metropolis?

3. Do effective and efficient customer service unit affect customers' loyalty in food and beverage firms in Port Harcourt metropolis? 


\section{Hypotheses}

The following null hypothesis will be tested for this work:

Ho1: there is no significant relationship between considerable pricing system and customers' repeat purchase in food and beverage firms in Port Harcourt metropolis.

$\mathbf{H o}_{2}$ : there is no significant relationship between quality product and service offering and customers' referral in food and beverage firms in port Harcourt metropolis.

Ho Here $_{\text {in }}$ tho significant relationship between effective and efficient customer service unit and customers' loyalty in food and beverage firms in Port Harcourt metropolis.

\section{Review of Related Literature Conceptual Framework \\ Relationship Marketing}

Relationship marketing includes making, keeping up, and improving the solid relationship with clients and different partners inside and outside ones ventures (Ibidunmi, 2012). As per Zeithaml and Bitner (2001), relationship marketing is a way of thinking of working together, a vital direction that centers around keeping and improving current clients, instead of procuring new consumers. Hence, keeping up long-standing relationships with the client is the methods for remaining serious in the advanced business world.

\section{Relationship Marketing Dimensions \\ Considerable Pricing System}

A price framework gauges the wants of consumers as far as the prices they are eager to pay for different amounts of every product or service rendered. The installment for the administrations of a gifted specialist (a price much impacted by the quantity of specialists) mirrors the one of a kind sort of those abilities for the purchaser quiet, while the price of an electric popcorn popper mirrors the minor comfort it gives. Obviously, the sum consumers consent to pay will be affected by their riches just as their wants, yet for any single consumer, relative want is corresponding to the price advertised.

The price you set for an item or service has a noteworthy impact on how the consumer carries on. In the event that consumers accept that the price you're charging is lower than contenders it could cause a significant spike in deals. Yet, on the off chance that the price you set is essentially higher than anticipated, the reaction can be baffling. In either case an adjustment in price could deliver surprising outcomes with regards to consumer buying behaviour (Balle 2019).

\section{Quality Product and Service Offering}

In market offering, an product is the key component that carries an incentive to the client. Items are something other than substantial articles yet in addition comprehensive of administration highlights, structure, execution quality, brand name and bundling. An item's quality has a noteworthy effect towards the item or administration execution, subsequently it is connected to a client's worth and fulfillment (Kotler and Armstrong, 2010).

Consumers buy goods or services based on fulfilling their perceived needs (palmer, 2001). The decision of this item to fulfill specific needs relies upon the view of the consumer about the item quality equipped for the fantastic that needs. As indicated by Perrault et al (1997). Numerous business Administrators get enveloped with the specialized subtleties associated with creating an item, however most clients or consumers consider item regarding the quality and the all out fulfillment it gives.

Toward this path, the main route for an organizations item to get by in the Market and to structure an item with the factors that consumers use to decide goods quality. Various consumers see quality in various turns. Some have the recognition that, item with excessive cost is of high caliber to one consumer might be a second rate compared to someone else.

In Ghana for example individuals see goods being sold in markets and retail locations to be of a high quality.Although a portion of the characteristics of value must be estimated unbiasedly, quality 
must be estimated regarding purchasers recognition (Kotler e tal 1999).

\section{Effective and Efficient Customer Service Unit}

Ward (2014), characterizes customer service as an institution's capacity to fulfill the necessities and needs of its consumers. customerservice in the food and beverage industry has grown astoundingly through the span of time. The spotlight has been for the most part on holding clients for as far as might be feasible to help deals, remembering that it costs more than double the sum to draw another client than keep an old one (Ahmed, Rahman and Rahman 2009).

The capacity of a firm to perform well and stay serious in the Nigerian food and beverages subpart of the production business is to a great extent subject to the arrangement of powerful and productive customer service unit. It is important for firms to consider the client as a basic aspect of the because of the cost ramifications in obtaining them, despite the fact that it is very amazing that a few associations give little consideration at conveying elevated levels of customer service.

\section{Consumer Buying Behavior}

A consumer is a notable individual who can settle on the choice to buy a thing from a specific store, and can be influenced by marketing and promotions.

Consumer buying behavior implies something beyond how an individual purchase goods. Marketing endeavors accordingly additionally center around consumer's utilization of services, his works and thoughts. It clarifies the arrangement of choices that a consumer makes while buying (Hoyer, 2004)1. It is imperative to know consumer response towards various items, their highlights, price, and notice design, so as to guarantee solid upper hand.

Consumer buying is the cycle included when people or institutions select, use, or arrange goodss, services, innovations or encounters (trade) to fulfill needs and wants. Consumer behaviour is the logical learning of how individuals purchase, what they like to purchase, when they have to purchase and why they purchase for example the motivation to purchase. It blends components from brain science, humanities, social science, and financial matters. It puts forth an attempt to comprehend the purchaser choice cycles or the purchaser dynamic cycle, both exclusively and in gatherings. It inspects unique qualities of individual consumers, for example, socioeconomics, psychographics, and conduct factors trying to comprehend the necessities of the individuals. It additionally attempts to survey effects on the consumer with the assistance of gatherings, for example, family, companions, reference gatherings, and society at large.

\section{Measures of Consumer Buying Behaviour}

\section{Customers' Repeat Purchase}

Repeat purchase can be attributed to reliable support that is worn out of clients' fulfillment with a particular item from a similar association. It can likewise be viewed as the buying of an item or administrations by a consumer of a similar brand. Rehash buy clients are clients who are fulfilled inwardly, mentally, truly by an association offering which could be in type of an item which surpasses their desires. Thus, the degree to which a client will disparage the food and beverage beverages of makers relies upon how the client sees the goods or service and how the client likewise thinks and feels that the price, advancements, packaging and the goods taste will give him/her the most extreme fulfillment.

\section{Customer Referrals}

Referral is the demonstration of guiding somebody to a better place or individual for data, help, or activity, frequently to an individual or gathering with more information or force (Cambridge English Word reference). Client referrals are one of the most remarkable selling and marketing apparatuses accessible. Actually, the best wellspring of new business is a referral from a fulfilled client. As per Forrester Exploration, 71 percent of online customers read surveys before buying. Different investigations additionally show that clients likewise state that referrals are absolutely critical in figuring out who they purchase from and what they purchase. 
Given the business potential from accumulating client referrals, it's essential to realize how to get great informal exchange from your regulars. Having the option to assemble a high level of business from clients, and even possibilities, through referrals is a fortunate quality of extraordinary deals experts. The food and beverage firms are much the same as some other firm where client maintenance is a critical factor to progress.

\section{Customer Loyalty}

Loyalty advancement is the essential worry of relationship marketing (Sheth, 1996). Client loyalty is a client's ability to keep disparaging a firm over the long haul, ideally on a select premise, and prescribing the company's items to companions and partners (Lovelock and Wirtz 2011). Clients show client loyalty when they reliably buy a specific item or brand over an all-inclusive timeframe. For instance, numerous clients adhere to a movement administrator because of the positive encounters they have had with their items and administrations. Client loyalty is broadly observed as a key determinant of a company's gainfulness. Consolidating the statutes of the client loyalty hypothesis into every day dealings can impact the making of more business (Michelle, 2018).

\section{Theoretical Framework}

\section{The Theory of Buyer Behaviour}

Howard built up the main consumer decision- model in 1963 (Du Plessis, Rousseauet al. 1991). This model was grown further in 1969 by Howard and Sheth to turn into the 'Hypothesis of Buyer Behavior' (or Howard and Sheth Model) (Howard and Sheth 1969). It gives "a complex combination of the different social, mental and marketing impacts on consumer decision into a lucid arrangement of data handling" (Foxall1990 p.10). The creators intrigue was in developing an exhaustive model that could be utilized to break down a wide scope of buying situations, and as such the term 'purchaser' was favored over 'consumer' in order to not bar business buys (Loudon AND DellaBitta 1993).

The model draws vigorously on learning hypothesis ideas (Loudon and Della 1993), and as such six learning builds are spoken to:

- Motive - depicted as either broad or explicit objectives inducing activity.

- Evoked Set - the consumers' appraisal of the capacity of the utilization decisions that are under dynamic thought to fulfill their objectives.

- Decision go between - the purchaser's psychological standards or heuristics for surveying buy options.

- Predispositions - an inclination toward brands in the evoked set communicated as a demeanor toward them.

- Inhibitors - natural powers, for example, restricted assets (for example time or monetary) which limit the utilization decision.

- Satisfaction - speaks to an input component from present buy reflection utilized on illuminate resulting choices.

This cycle of learning serves to impact the degree to which the consumer thinks about future buys, and looks for new data. Howard and Sheth recommended that consumer dynamic varies as indicated by the quality of the disposition toward the accessible brands; this being to a great extent represented by the consumer's information and experience with the item class. In circumstances where the consumer doesn't have solid perspectives they are said to participate in Extended Problem Solving (EPS), and effectively look for data so as to lessen brand uncertainty. In such circumstances the consumer will likewise embrace delayed consideration before choosing which item to buy or for sure, regardless of whether to make any buy. As the item bunch turns out to be more recognizable, the cycles will be embraced less scrupulously as the consumer attempts Limited Problem Solving (LPS) and inevitably Routine Problem Solving (RPS) (Foxall 1990). 


\section{Empirical Framework}

Shahram Gilaninia and Behzad Gholami Ghashlagh (2012)

Shahram \& Behzad (2012). Directed an investigation named; Relationship marketing framework and its effect on consumer buying behavior. The motivation behind this examination is sway relationship marketing on client buying behavior. Measurable society of this examination was incorporated all clients of Audio and Video Stop in the city of Ardabil in 1390 that was chosen 378 to available inspecting. For information investigation in the examination have utilized from Lisrel programming and measurable methods of auxiliary conditions displaying (SEM). The outcomes show that there is critical relationship between relationship Marketing framework and Retention Orientation of the Retailer from sound and video Shops. There is critical relationship between relationship Satisfaction, personalization of shop, Rewarding of shop, shop Communications with Retention Orientation of the Retailer however there isn't noteworthy relationship between particular medicines of shop and Retention Orientation of the Retailer. Additionally there is noteworthy relationship between trusts to shop with relationship Satisfaction and Relationship Commitment.

\section{Nwulu, chinyere Stella and Nwokah, N. Gladson (2018)}

Nwulu \& Nwokah (2018). Customer service management and marketing valuation of food and beverage firms in Nigeria. This examination explores the relationship between client assistance the board and marketing execution of food and beverage fabricating firms in Nigeria. The structure is the cross sectional overview and information is created from fifteen (15) cited fabricating firms in the nation. Relationships are surveyed dependent on invalid speculative articulations which analyze the unimportance of the impact of client assistance the executives on three proportions of marketing execution: deals development, piece of the pie and productivity; utilizing the Spearman's rank request connection. All speculations were dismissed dependent on the proof of noteworthy relationship between the factors. The investigation, in accordance with its discoveries certified that client support the executives contributes altogether to marketing execution subsequently upgrading measures, for example, deals development, piece of the pie and benefit of food and beverage firms in the Nigerian manufacturing industry.

\section{Summary of Literature Review}

The study focused on relationship marketing and consumer buying behavior. Relationship marketing it was revealed that creating a good relationship with customers goes a long way to influence their buying behavior. The best approach to maintaining customer is noted to create much Satisfaction in customer and things valuable for them because as a result his loyalty increase towards company strongly. The dimensions of relationship marketing were discussed to include : considerable pricing system, quality product and service offering and effective and efficient customer service unit.

\section{Methodology}

This research study adopted the descriptive survey research design. The populations are all telecommunication users in Port Harcourt metropolis and a sample size of 375 persons were randomly selected while 358 questionnaires were successfully retrieved and used for the analysis. Sample size was determined using Morgan Krejcie table. Data was collected by use of questionnaire. The questionnaires were developed in line with the purpose of the study and were finally validated by experts in marketing department. Reliability was measured using test- retest method for its measure of consistency and stability of the instrument and a reliability coefficient of 0.78 was gotten which shows an acceptable level of reliability. The questionnaires were administered to the telecom users at different locations with the aid of two research assistance who were trained by the researcher on data administration for this very purpose. Data were analysed using descriptive statistics (mean and standard deviation) while inferential statistics Pearson Product Moment Correlation (PPMC) was used to test the above stated hypotheses at 0.05 level of significance. 


\section{Analysis and Result}

The chapter presents the analysis and interpretation of data collected in respect to this study. This chapter of the research further presents the conclusion and made recommendations.

\section{Research Question 1}

Does considerable pricing system affect customers' repeat purchase in the food and beverage firms in Port Harcourt Metropolis?

Table 1: Computation of customers' responses on considerable pricing system and customers' repeat purchase in food and beverage firms in Port Harcourt. $(\mathrm{N}=358)$.

\begin{tabular}{|c|c|c|c|c|c|c|c|c|c|}
\hline SiN & Item(s) & SA & $\mathbf{A}$ & $\mathbf{D}$ & SD & $\begin{array}{l}\text { Total } \\
\text { Resp }\end{array}$ & Mean & SD & Decision \\
\hline \multirow[t]{2}{*}{1} & Customers & 56 & 119 & 101 & 82 & & & & \\
\hline & $\begin{array}{l}\text { products that have } \\
\text { considerable prices. }\end{array}$ & 224 & 357 & 202 & 82 & 865 & 2.42 & 0.79 & Disagree \\
\hline 2 & $\begin{array}{l}\text { Products that sell more are } \\
\text { the ones that the ir prices are } \\
\text { affordable. }\end{array}$ & $\begin{array}{l}66 \\
264\end{array}$ & $\begin{array}{l}105 \\
315\end{array}$ & $\begin{array}{l}96 \\
192\end{array}$ & $\begin{array}{l}91 \\
91\end{array}$ & 862 & 2.41 & 0.71 & Disagree \\
\hline 3 & $\begin{array}{l}\text { There is a high demand for } \\
\text { products with considerable } \\
\text { prices. }\end{array}$ & $\begin{array}{l}74 \\
296\end{array}$ & $\begin{array}{l}101 \\
303\end{array}$ & $\begin{array}{l}107 \\
214\end{array}$ & $\begin{array}{l}76 \\
76\end{array}$ & 889 & 2.48 & 0.78 & Disagree \\
\hline \multirow[t]{2}{*}{4} & $\begin{array}{l}\text { Customers perception of } \\
\text { over expensive products is } \\
\text { assesed through irregular } \\
\text { dernands of the product. }\end{array}$ & $\begin{array}{l}86 \\
86\end{array}$ & $\begin{array}{l}124 \\
248\end{array}$ & $\begin{array}{l}87 \\
261\end{array}$ & $\begin{array}{l}61 \\
244\end{array}$ & 839 & 2.34 & 0.76 & Disagree \\
\hline & Grand Mean & & & & & & 2.41 & 0.75 & Disagree \\
\hline
\end{tabular}

Source: Field survey, 2018

Analysis in table 1, showed that all items in the scale had a weighted mean scores below the criterion mean of 2.50 and thus, were rejected that considerable pricing system affect customers' repeat purchase in food and beverage firms in Port Harcourt. In summary, with a grand mean of 2.41, the customers confirmed that the food and beverage firms in Port Harcourt lack considerable pricing system which affect consumer customers' repeat purchase negatively.

\section{Research Question 2}

Do quality product and service offering enhance customers' referral in food and beverage firms in Port Harcourt Metropolis?

Table 2: Computation of customers' responses on quality product and service offering and customers' referral in food and beverage firms in Port Harcourt. $(\mathrm{N}=358)$. 


\begin{tabular}{|c|c|c|c|c|c|c|c|c|c|}
\hline SIN & Item(s) & SA & $\mathbf{A}$ & $\mathbf{D}$ & SD & $\begin{array}{l}\text { Total } \\
\text { Resp }\end{array}$ & Mean & SD & Decision \\
\hline 1 & $\begin{array}{l}\text { Customers may discontinue } \\
\text { with the use of a firm's } \\
\text { products if they are not up } \\
\text { to standard. }\end{array}$ & $\begin{array}{l}96 \\
384\end{array}$ & $\begin{array}{l}158 \\
474\end{array}$ & $\begin{array}{l}57 \\
114\end{array}$ & $\begin{array}{l}47 \\
47\end{array}$ & 1019 & 2.85 & 0.79 & Agree \\
\hline 2 & $\begin{array}{l}\text { Poor quality of products and } \\
\text { services give rise to limited } \\
\text { sales. }\end{array}$ & $\begin{array}{l}24 \\
96\end{array}$ & $\begin{array}{l}66 \\
198\end{array}$ & $\begin{array}{l}162 \\
324\end{array}$ & $\begin{array}{l}106 \\
106\end{array}$ & 724 & 2.02 & 0.71 & Disagree \\
\hline 3 & $\begin{array}{l}\text { Customers patronize a } \\
\text { company's products and } \\
\text { services if they have good } \\
\text { quality. }\end{array}$ & $\begin{array}{l}112 \\
448\end{array}$ & $\begin{array}{l}102 \\
306\end{array}$ & $\begin{array}{l}70 \\
140\end{array}$ & $\begin{array}{l}74 \\
74\end{array}$ & 968 & 2.70 & 0.78 & Agree \\
\hline 4 & $\begin{array}{l}\text { Customers might not refer } \\
\text { others to a firm's product if } \\
\text { it is not of good quality. }\end{array}$ & $\begin{array}{l}68 \\
272\end{array}$ & $\begin{array}{l}88 \\
264\end{array}$ & $\begin{array}{l}131 \\
262\end{array}$ & $\begin{array}{l}71 \\
71\end{array}$ & 869 & 2.43 & 0.76 & Disagree \\
\hline & Grand Mean & & & & & & 2.50 & 0.75 & Agree \\
\hline
\end{tabular}

Source: Field survey, 2018

Table 2, shows quality product and service offering and its impact on customers' referral in the food and beverage firms in Port Harcourt. items 1 and 3 have item mean between 2.85 and 2.70 respectively which are higher than the criterion mean of 2.5; while items 2 and 4 have item mean ranging 2.02 and 2.43 had a mean score below the criterion mean and thus were rejected. The grand mean of 2.50 the respondents agree that quality product and service offering enhance customers' referral in food and beverage firms in Port Harcourt.

\section{Research Question 3}

Do effective and efficient customer service unit affect customers' loyalty in food and beverage firms in Port Harcourt Metropolis?

Table 3: Computation of customers' responses on effective and efficient customer service unit and customers' loyalty in food and beverage firms in Port Harcourt. $(\mathrm{N}=358)$.

\begin{tabular}{|c|c|c|c|c|c|c|c|c|c|}
\hline SIN & Item(s) & SA & $\mathbf{A}$ & $\mathbf{D}$ & SD & $\begin{array}{l}\text { Total } \\
\text { Resp }\end{array}$ & Mean & SD & Decision \\
\hline 1 & $\begin{array}{l}\text { Customers are loyal to firms } \\
\text { that render effective and } \\
\text { efficient customer service. }\end{array}$ & $\begin{array}{l}101 \\
404\end{array}$ & $\begin{array}{l}122 \\
366\end{array}$ & $\begin{array}{l}86 \\
172\end{array}$ & $\begin{array}{l}49 \\
49\end{array}$ & 991 & 2.77 & 0.79 & Agree \\
\hline 2 & $\begin{array}{l}\text { Unstable customer service } \\
\text { reduces a firm's committed } \\
\text { customer base. }\end{array}$ & $\begin{array}{l}76 \\
76\end{array}$ & $\begin{array}{l}89 \\
178\end{array}$ & $\begin{array}{l}100 \\
300\end{array}$ & $\begin{array}{l}93 \\
372\end{array}$ & 926 & 2.59 & 0.71 & Agree \\
\hline 3 & $\begin{array}{l}\text { Prompt response to } \\
\text { customers and addressing } \\
\text { their complaints instigates } \\
\text { their preference over } \\
\text { another. }\end{array}$ & $\begin{array}{l}91 \\
364\end{array}$ & $\begin{array}{l}164 \\
492\end{array}$ & $\begin{array}{l}84 \\
168\end{array}$ & $\begin{array}{l}19 \\
19\end{array}$ & 1043 & 2.91 & 0.78 & Agree \\
\hline 4 & $\begin{array}{l}\text { providing, solutions to } \\
\text { customers' complaints } \\
\text { enthance their loyalty to a } \\
\text { firm. }\end{array}$ & $\begin{array}{l}89 \\
89\end{array}$ & $\begin{array}{l}109 \\
218\end{array}$ & $\begin{array}{l}97 \\
291\end{array}$ & $\begin{array}{l}63 \\
252\end{array}$ & 850 & 2.37 & 0.76 & Agree \\
\hline & Grand Mean & & & & & & 2.66 & 0.75 & Agree \\
\hline
\end{tabular}

Source: Field survey, 2018 
Table 3, shows Computation of customers' responses on effective and efficient customer service unit and customers' loyalty in the food and beverage firms in Port Harcourt. The four (4) questionnaire items have the following mean 2.77, 2.59, 2.91 and 2.37 respectively. However, the grand mean of 2.66 was higher than the criterion mean of 2.50 the respondents agreed that effective and efficient customer service unit affect customers' loyalty of the food and beverage firms in port Harcourt.

Hypothesis 1:

There is no significant relationship between considerable pricing system and customers' repeat purchase in the food and beverage firms in Port Harcourt Metropolis.

Table 4 Computation of relationship between considerable pricing system and customers' repeat purchase in the food and beverage firms in Port Harcourt.

\begin{tabular}{lcccccc}
\multicolumn{1}{c}{$\begin{array}{l}\text { Variables } \\
\text { Dec }\end{array}$} & & $\sum \mathbf{X}$ & $\sum \mathbf{X}^{\mathbf{2}}$ & $\mathbf{D F}$ & r-cal & r-crit \\
& $\sum \mathbf{Y}$ & $\sum \mathbf{Y}^{\mathbf{2}}$ & $\sum \mathbf{X Y}$ & & & \\
\hline $\begin{array}{l}\text { Considerable } \\
\text { Pricing }\end{array}$ & 890 & 33132 & & & & \\
& & & 356 & & & \\
& & & 35010 & 3.54 & 0.1946 & Reject \\
Repeat Purchase & 710 & 40702 & & & & \\
\hline & & $\mathbf{p}>\mathbf{0 . 0 5}$ & & *significant & $\mathbf{N}=\mathbf{3 5 8}$
\end{tabular}

In table 4.4.the calculated $r$ is 3.34 and the critical value of $r$ was 0.1946 . this means that the calculated $r$ is statistically significant at $\mathrm{p}>0.05$ since it is greater than the critical value of $r$. therefore, the hypothesis $\left(\mathrm{Ho}_{1}\right)$ is rejected that considerable pricing system enhances customers' repeat purchase and the conclusion is that there is no significant relationship between considerable pricing system and customers' repeat purchase the food and beverage firms in Port Harcourt.

\section{Hypothesis 2}

There is no significant relationship between quality product and service offering and customers' referral in the food and beverage firms in Port Harcourt metropolis.

Table 5 Computation of relationship between quality product and service offering and customers' referral in the food and beverage firms in Port Harcourt.

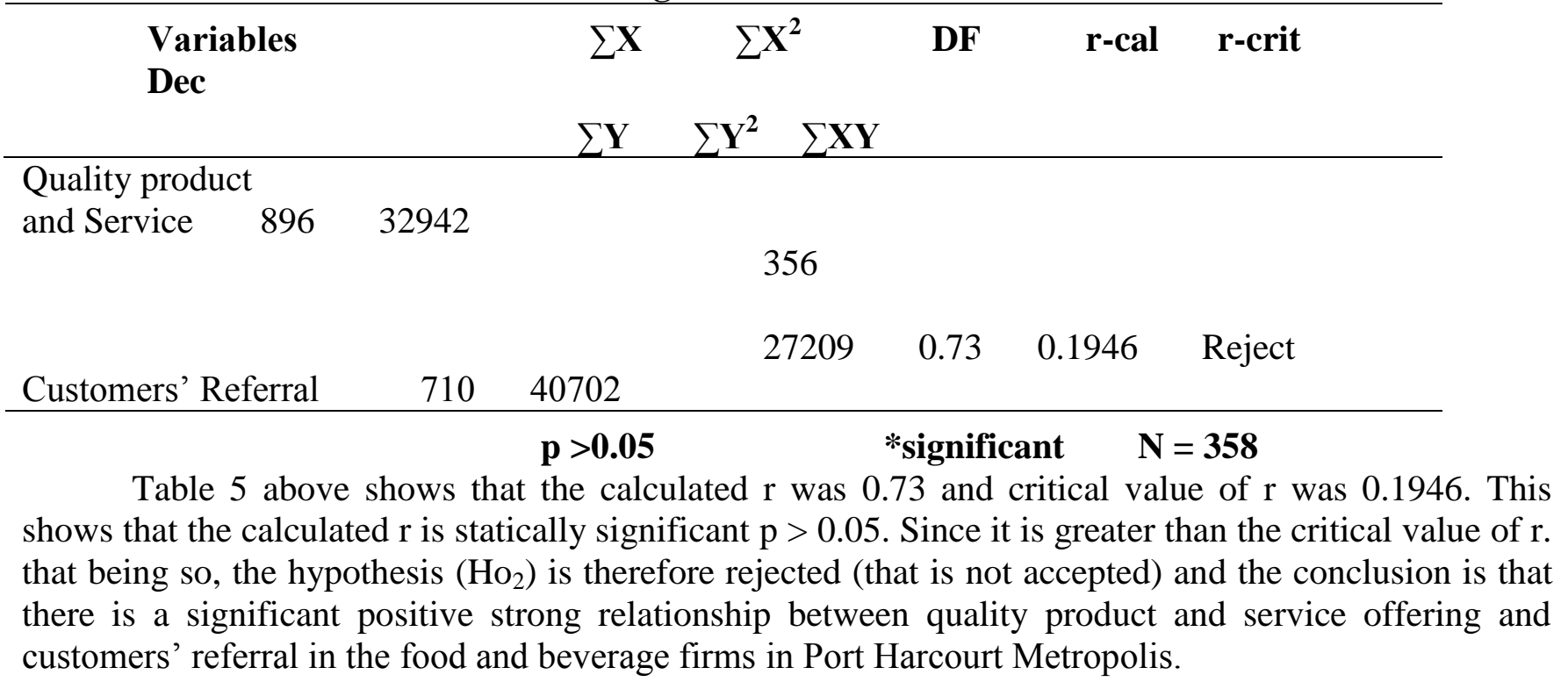




\section{Hypothesis 3}

There is no significant relationship between effective and efficient customer service unit and customers' loyalty in the food and beverage firms in Port Harcourt metropolis.

Table 6: Computation of relationship between effective and efficient customer service unit and customer loyalty in the food and beverage firms in Port Harcourt metropolis.

\begin{tabular}{|c|c|c|c|c|c|c|c|}
\hline \multirow[t]{2}{*}{$\begin{array}{l}\text { Variables } \\
\text { Dec }\end{array}$} & & \multicolumn{2}{|c|}{$\sum \mathbf{X}$} & $\sum \mathbf{X}^{2}$ & DF & \multirow[t]{2}{*}{ r-cal } & \multirow[t]{2}{*}{ r-crit } \\
\hline & & $\sum \mathbf{Y}$ & $\sum \mathbf{Y}^{2}$ & $\sum \mathbf{X Y}$ & & & \\
\hline \multicolumn{8}{|l|}{ Effective and efficient } \\
\hline \multirow[t]{3}{*}{ Customer Service } & 956 & 34162 & & & & & \\
\hline & & & & 356 & & & \\
\hline & & & & 29663 & 0.55 & 0.1946 & Reject \\
\hline Customer Loyalty 710 & & & & & & & \\
\hline
\end{tabular}

Table 6 above shows that the calculated $r$ was 0.55 and critical value of $r$ was 0.1946 . This shows that the calculated $r$ is statically significant $p>0.05$. Since it is greater than the critical value of $r$. that being so, the hypothesis $\left(\mathrm{Ho}_{3}\right)$ is therefore rejected (that is not accepted) and the conclusion is that there is a significant relationship between effective and efficient customer service unit and customers' loyalty in the food and beverage firms in port Harcourt Metropolis.

\section{Conclusion}

The mean results of respondents show that quality product and service offering impact customer referral in the food and beverage firms in Port Harcourt. However, considerable pricing system does not influence customer repeat purchase. The PPMC results reveal that there is a significant relationship between effective and efficient customer service unit and customer service unit and customer loyalty in the food and beverage firms in Port Harcourt. In summary, relationship marketing enhance consumer buying in the food and beverage firms in Port Harcourt.

\section{Recommendations}

$\checkmark$ The food and beverage firms in Port Harcourt should be more responsible in providing considerable pricing system so as to attract customers to repeat purchase. Putting this in place, will increase the profit of the firm.

$\checkmark$ In respect to quality product and service offering, it is expedient that the food and beverage firms in Port Harcourt should implement policies to improve the quality of products and services rendered to customers. This will invariably stimulate customers to refer others to the firm's products and services.

$\checkmark$ Furthermore, the food and beverage firms in Port Harcourt should prioritize the stabilization of an effective and efficient customer service unit in order to maintain a maximum degree of customer loyalty.

\section{References}

1. Batey, S. \&Kazmi K. (2004), Consumer Behavior, p.523, Excel books, New Delhi

2. Blackwell, R. Miniard, P. \& Engel (2007) Consumer Behaviour, pp 121-122, The Dryden press, South-Western, Ohio, 
3. Gumas, P. Gordan F. Ronald G. \& Stephen B. (2009). Consumer Psychology for Marketing, p.329, International Thomson Business Press. Foxall.

4. Damirchi, F. \& Zadbagher,F.(2011), Comparative Study of Relationship Marketing In Public and Private Banks, interdisciplinary journal of contemporary research in business, ijcrb.webs.com 3(8), 508-514.

5. Kapferer, W., \& Prothero A. \& McDonagh P. (2004), Sustainable Consumption and the quality of life: Amacromarketing challenge to the dominant social paradigm. Journal of Macro Marketing. 17(1), 4-24

6. Kotler, P. \& Armstrong, G. (2005), Marketing: A Conceptual Introduction, Marketing Management, 1(6), 322-362, Pearson Education, New Jersey.

7. Krejcie, R. V. \& Morgan, D. W. (1970). Determining sample size for research activities. Educational and Psychological Management, 30, 607-610.

8. Ndubisi, O. N. (2007), "Relationship marketing and customer loyalty" Marketing intelligence \& planning, 25(1), 98-106.

9. Kapferer, W., \& Prothero A. \& McDonagh P. (2004), Sustainable Consumption and the quality of life: Amacromarketing challenge to the dominant social paradigm. Journal of Macro Marketing. 17(1), 4-24

10. Kotler, P. \& Armstrong, G. (2005), Marketing: A Conceptual Introduction, Marketing Management, 1(6), 322-362, Pearson Education, New Jersey.

11. Krejcie, R. V. \& Morgan, D. W. (1970). Determining sample size for research activities. Educational and Psychological Management, 30, 607-610.

12. Ndubisi, O. N. (2007), "Relationship marketing and customer loyalty" Marketing intelligence \& planning, 25(1), 98-106.

13. Kapferer, W., \& Prothero A. \& McDonagh P. (2004), Sustainable Consumption and the quality of life: Amacromarketing challenge to the dominant social paradigm. Journal of Macro Marketing. 17(1), 4-24

14. Kotler, P. \& Armstrong, G. (2005), Marketing: A Conceptual Introduction, Marketing Management, 1(6), 322-362, Pearson Education, New Jersey.

15. Krejcie, R. V. \& Morgan, D. W. (1970). Determining sample size for research activities. Educational and Psychological Management, 30, 607-610.

16. Ndubisi, O. N. (2007), "Relationship marketing and customer loyalty" Marketing intelligence \& planning, 25(1), 98-106.

17. Odekerken-Schroder, G., De Wulf, K.\& Schumacher, P. (2003), "Strengthening Outcomes of Retailer-Consumer Relationships: The Dual Impact of Relationship Marketing Tactics and Consumer Personality", Journal of Business Research, 56(3), 177-190.

18. Ranjbariyan, Bahram, Mojtaba, \& Barari (2009), "Relationship marketing, an approach for improving customer satisfaction", Iranian Journal of Management Executive, No. 2 (6), 15-34.

19. Ranka V., Tsalikis J., \& Seaton B.(2006), Measuring Consumer Sentiments towards Business Ethics, Journal of Business Ethics, 9(5), 184-191.

20. Schroder G., Wulf, K \& Schumacher P.(2003), Strengthening Outcomes of Retailer-consumer Relationships Thedual Impact of Relationship Marketing Tactics and Consumer Personality. Journal of Business Research; 5(6), 177- 190.

21. Uko, R. (2018), Quality management practices and performance of food and beverage firms in port Harcourt, International Journal of Advanced Academic Research; 4(2), 77-92

22. Zins, A. H. (2001), "Relative attitudes and commitment in customer, loyalty models", International Journal of Service Industry Management. 12(3), 269-294.

23. Ranka V., Tsalikis J. \& Seaton B. (2006), Measuring Consumer Sentiments towards Business Ethics, Journal of Business Ethics, 8(9), 184-190. 